\title{
PRODUCTIVITY AND QUALITY OF SUGAR CONTENT, TOTAL ACID, PH, AND GANDARIA FRUIT WATER LEVELS (BOUEA MACROPHYLLA GRIIFF) IN DIFFERENT GEOGRAPHICAL CONDITIONS IN AMBON ISLAND (AN ANALYSIS OF MALUKU ENDEMIC PLANTS).
}

\author{
Pamella Mercy Papilaya \\ Biology Education Study Program Faculty of Teacher Training and Education \\ Pattimura University \\ Email: joyfullpamela@yahoo.co.id
}

\begin{abstract}
Gandaria plant grows with tree habitus with a height of up to $27 \mathrm{~m}$ Spread of gandaria plants in Maluku, generally on Ambon Island and Saparua on Ambon Island, gandaria plants are spread from the coast to the hills. This study aims to determine the quality of sugar content, total acid, $\mathrm{pH}$, water content and production of gandaria fruit (Bouea macrophylla Griff) in different geographical conditions on the island of Ambon using a purposive sampling method and laboratory analysis. The results showed that at an altitude of $0-400$ asl with a production of $654 \mathrm{~kg}, 400-700$ asl with a production of $681 \mathrm{~kg}$ and an altitude of 700-1100 asl producing $925 \mathrm{~kg}$ and the height of the place also affected the quality of gandaria with an average total sugar of $12.69 \%$, content water $80.18 \%$, acidity level $6.81 \%$ and $\mathrm{pH} 3$. It was concluded that the higher the altitude of the place will affect the production and quality of gandaria fruit (Bouea macrophylla Griff).
\end{abstract}

Keywords: Gandaria, sugar content, total acid, $\mathrm{pH}$, water content, production, geographical conditions, Ambon island.

\section{Introduction}

Gandaria (Bouea macrophylla Griff) is one of Maluku's local plants, has a habitus with a tree height of $27 \mathrm{~m}$ with a tight canopy. The leaves are single, oval shaped round eggs to form lancet or jorong. When young, white, then gradually dark purple, then dark green. Inflorescence begins, appears in the armpit of the leaf, the fruit is of stone fruit type, rather round in shape, $2.5-5 \mathrm{~cm}$ in diameter, yellow to orange, the flesh emits a thick liquid, the fruit is hairless, tastes sour to sweet, with a characteristic odor approaching smell of turpentine.

Lavender seeds. Gandaria is a wet tropical plant and can grow on light and fertile soils that grow wild in lowland forests below $300 \mathrm{~m}$ above sea level, but in cultivation it has been successfully planted at an altitude of around $850 \mathrm{~m}$ above sea level (Rehatta, 2005). Gandaria (B. macrophylla Griff) has a spacing of spacing of 10-12 meters, can grow to elevation of $1-500$ asl, the beginning of the flowering season at the beginning of the dry season and the time of fruiting in December to February (Harjadi et al 2011). Gandaria (B. macrophylla Griff) is one of the Anacadiaceae tribes which is a megatherm which is limited and rare in Maluku. These species spread to heights above $3000 \mathrm{~m}$ above sea level (Monk et al, 2000).

Heyne (1987) explains that Gandaria is an endemic species of the Maluku region that has wild plants at an altitude of 500 meters to 800 meters above sea level. Although in theory the ability to grow at an altitude, but in fact in Ambon can grow below $500 \mathrm{~m}$ above sea level and above $800 \mathrm{~m}$ above sea level. This means that Gandaria has a high adaptability to the surrounding environment.

In the tropics it is generally characterized by almost uniform climatic conditions. But with geographical differences such as differences in altitude above sea level (asl) will

Received October $10^{\text {th }} 2019$, Revision Februrry $9^{\text {th }} 2020$, Accepted for publication February $18^{\text {th }} 2020$. Copyright (C) 2020 Published by FKIP - Unpatti, ISSN 2721-3110 
lead to differences in weather and overall climate in these places, especially temperature, humidity and rainfall. The weather and climate elements are mostly controlled by the location of latitude, altitude, distance from the sea, topography, soil type and vegetation. In the lowlands is characterized by ambient temperature, high air pressure and oxygen. While the highlands influence the decrease in air pressure and air temperature and increased rainfall. The rate of temperature decrease due to altitude varies in each place (Sangadji, 2001). The average decrease in air temperature in Indonesia is around 0.50.60C per 100 meter increase (Handoko, 1995).

In addition to its high vitamin content, (B.macrophylla Griff) has a high enough calorie content. Thus it can provide substitution of calorie needs from rice and other crops which are still in the stage of being fought for with the term PPH (Food Pattern of Hope of 2400 Calories / day / person). In many areas, especially in rural areas sometimes the PPH never reaches its hum even, so the taste is not lacking in food, but in fact it is still inadequate. Especially in areas that are prone to famine (Harjadi et al 2011) ..

The Gandaria (B.macrophylla Griff) plant originates from Southeast Asia and is currently scattered from Indonesia, Malaysia and America with a tropical climate. Gandaria is a very unique Maluku tropical fruit plant and is known as exotic fruit (Rehatta, 2005). The gandaria tree is very suitable to grow in wet tropical regions with fertile soil. Naturally gandaria grows in lowland forests to an altitude of 300-500 m above sea level. Distribution of Gandaria plants (B. macrophylla Griff) in Maluku, generally on Ambon Island and Saparua on Ambon Island, gandaria plants are spread from the coast to the hills (Tangkuman, 2006) on Ambon Island the gandaria plants can grow and produce well. Gandaria is also one of the typical Maluku fruit crops that needs to be cultivated because it is beneficial both economically and ecologically.

Sinay (2011), explains that young gandaria fruits are green and consumed as a mixture of sambal, rujak and lalap. The gandaria tastes good and is loved by the people of Maluku as well as by tourists who come to visit Maluku. Generally gandaria fruit by tourists who visit Maluku is used as souvenirs. The gandaria fruit (B. macrophylla Griff) which is ripe yellow and has a sweet sour taste can be consumed directly as a table fruit (Kurniawan and Bayu, 2010) as fruit juice (iced fruit) fruit (Rehatta, 2005). According to Syamsudin (2007), gandaria is a fruit that is eaten fresh and can also be made jam and syrup, while young gandaria fruit is specifically used for making pickles and chilli sauce. on different geographical conditions on the island of Ambon.

\section{Research Methods}

This research is correlational used to reveal the relationship of altitude from sea level to the quality and production of gandaria fruit (Bouea macrophylla Griff) on Ambon Island. This research was carried out at three different locations:

Table 1. Location Distribution Based on Altitude

\begin{tabular}{|c|c|c|}
\hline No & Altitude & Location \\
\hline 1. & $0-400 \mathrm{~m}$ above sea level & Hative Besar \\
\hline 2. & $400-700 \mathrm{~m}$ above sea level & Kusu-kusu \\
\hline 3. & $700<\mathrm{m}$ above sea level & Hatalai \\
\hline
\end{tabular}

The sampling method used is purposive sampling, which is the sampling technique used when the elements desired by the researcher are found in the samples taken (Nasution, 2003). The elements desired by researchers in this study include Gandaria fruit that is ripe and flesh of yellow gandaria fruit with a predetermined height.

This research was conducted by direct observation to the area where the growth of Gandaria plants. Sampling used 5 trees per study location with different height. The total number of Gandaria plants used was 15 Gandaria trees. As for the things to be examined included: the size of the gandaria fruit, the total production of Gandaria fruit,

Received October $10^{\text {th }} 2019$, Revision Februrry $9^{\text {th }} 2020$, Accepted for publication February $18^{\text {th }} 2020$.

Copyright (C) 2020 Published by FKIP - Unpatti, ISSN 2721-3110 
tree height, age of the tree and the circumference of the tree trunk.

To test the quality of the Gandaria fruit must be picked at a sufficient level of maturity if harvested before cooking it will affect the quality so that the quality of Gandaria cannot be known. Testing the quality of the Gandaria fruit will also be adjusted to the height of the place where there are a number of things that will be tested in the quality of the Gandaria test include:

a. Analysis of total acid

b. PH analysis

c. Analysis of sugar levels

d.Analysis of water content

Data analysis techniques in this study are: using descriptive statistics and inferential statistics. Descriptive statistics are used to describe the productivity data of Gandaria at several altitudes in the city of Ambon through tables and graphs. The international statistics used are simple linear regression tests to analyze the relationship of altitude to production and quality of gandaria. Before carrying out a simple linear regression test, a prerequisite test is required, namely the linearity test. The inferential test uses SPSS 21 statistics for windows with a confidence level of $5 \%$.

\section{Results and Discussion}

\section{a. Description of General Characteristics of Research Areas}

The Hative Besar Village of Ambon City is astronomically located geographically between $128^{\circ} 9^{\circ}-128^{\circ} 12^{\circ}$ East and $3^{\circ} 37^{\circ}-3^{\circ} 40$ South Latitude. Topographically, the Hative Besar Village is located at an altitude of $0-400 \mathrm{~m}$ above sea level. the state of the forest floor is flat. Podsolic soil type.

The Kusu - kusu hamlet of Ambon City is astronomically located geographically between $128^{\circ} 10^{\circ}-128^{\circ} 12$ east longitude and $3^{\circ} 42^{\circ}-3^{\circ} 45^{\circ}$ LS. Topographically Kusu-kusu Hamlet is located at an altitude of $500 \mathrm{~m}$ above sea level. At the location of this study, the state of the forest floor was generally hilly with rock boards and rocky slopes and figures. There are streams of small rivers that run out of coral fragments and flow throughout this region. Podosolic soil type.

The Ambon City Hatalai Hamlet that is encountered is not too much different. Morphology of the forest floor encountered varies among rocky and rocky planks. Astronomically, the geographical location is between $128^{\circ} 11^{\circ}-128^{\circ} 12^{\circ}$ East and $3^{\circ} 43^{\circ}$ $3^{\circ} 46^{\circ}$ South latitude. Land forms other than rocky and rocky, forming hills with wide plains. The type of soil found is the same as that found in the Kusu-kusu sub-village, podsolik. The topography of this village is located at $>700 \mathrm{~m}$ above sea level.

\section{b. Production}

Research on gandaria production. Production itself means a scientific comparison between the amount produced and the amount of each source used during the production period. Gandaria is a seasonal fruit or in other words does not bear fruit of all time. This causes during the harvest season the production of fruits is very abundant so during the harvest season, proper handling needs to be done. Production results are divided into several places according to different altitudes, there are three locations studied, namely: Big Hative, Kusu-kusu and Hatalai. Can be seen from Table 1-3, and Figure 1:

Received October $10^{\text {th }} 2019$, Revision Februrry $9^{\text {th }} 2020$, Accepted for publication February $18^{\text {th }} 2020$.

Copyright (C) 2020 Published by FKIP - Unpatti, ISSN 2721-3110 


\section{1) Production results in the Hative Besar Village}

Table 2. Production of Gandaria Fruit in Hative Besar Village

\begin{tabular}{cccccc}
\hline Hative Besar & Tree Height & Tree Age & $\begin{array}{c}\text { Ring } \\
\text { Circumference }\end{array}$ & $\begin{array}{c}\text { Fruit } \\
\text { circle }\end{array}$ & $\begin{array}{c}\text { Production Of } \\
\text { Tree }\end{array}$ \\
\hline Tree 1 & $10,3 \mathrm{~m}$ & 19 Tahun & $75 \mathrm{Cm}$ & & $90 \mathrm{Kg}$ \\
Tree 2 & $7,9 \mathrm{~m}$ & 35 Tahun & $168 \mathrm{Cm}$ & $11 \mathrm{~cm}$ & $132 \mathrm{Kg}$ \\
Tree 3 & $13,7 \mathrm{~m}$ & 40 Tahun & $178 \mathrm{Cm}$ & -13 & $160 \mathrm{Kg}$ \\
Tree 4 & $8 \mathrm{~m}$ & 30 Tahun & $118 \mathrm{Cm}$ & $\mathrm{cm}$ & $128 \mathrm{Kg}$ \\
Tree 5 & $8,6 \mathrm{~m}$ & 28 Tahun & $112 \mathrm{Cm}$ & & $144 \mathrm{Kg}$ \\
\hline
\end{tabular}

Source: research results

\section{2) Kusu kusu Hamlet Production}

Table 3 Production of Gandaria in the Kusu - Kusu Hamlet

Tabel 3 Produksi Buah Gandaria Pada Dusun Kusu-Kusu

\begin{tabular}{cccccc}
\hline Kusu-kusu & $\begin{array}{c}\text { Tree } \\
\text { Height }\end{array}$ & Tree Age & $\begin{array}{c}\text { Ring } \\
\text { Circumference }\end{array}$ & $\begin{array}{c}\text { Fruit } \\
\text { circle }\end{array}$ & $\begin{array}{c}\text { Production Of } \\
\text { Tree }\end{array}$ \\
\hline Pohon 1 & $11 \mathrm{~m}$ & 25 Tahun & $96 \mathrm{Cm}$ & & $131 \mathrm{Kg}$ \\
Pohon 2 & $12 \mathrm{~m}$ & 39 Tahun & $160 \mathrm{Cm}$ & & $145 \mathrm{Kg}$ \\
Pohon 3 & $15 \mathrm{~m}$ & 28 Tahun & $116 \mathrm{Cm}$ & $12 \mathrm{Cm}-$ & $136 \mathrm{Kg}$ \\
Pohon 4 & $9,5 \mathrm{~m}$ & 25 Tahun & $96 \mathrm{Cm}$ & $15 \mathrm{Cm}$ & $137 \mathrm{Kg}$ \\
Pohon 5 & $10 \mathrm{~m}$ & 32 Tahun & $139 \mathrm{Cm}$ & & $132 \mathrm{Kg}$ \\
\hline
\end{tabular}

Source: research results

\section{3) Hatalae Hamlet Production}

Tabel 4 Hatalai Hamlet Gandaria Fruit Production

\begin{tabular}{|c|c|c|c|c|c|}
\hline Hatalae & $\begin{array}{c}\text { Tree } \\
\text { Heigh }\end{array}$ & Tree Age & $\begin{array}{c}\text { Ring } \\
\text { Circumferen } \\
\text { ce }\end{array}$ & $\begin{array}{l}\text { Fruit } \\
\text { circle }\end{array}$ & $\begin{array}{c}\text { Production Of } \\
\text { Tree }\end{array}$ \\
\hline Pohon 1 & $7,9 \mathrm{~m}$ & 20 tahun & $82 \mathrm{~cm}$ & & $120 \mathrm{~kg}$ \\
\hline Pohon 2 & $8 \mathrm{~m}$ & 23 Tahun & $84 \mathrm{Cm}$ & $12 \mathrm{~cm}-$ & $145 \mathrm{Kg}$ \\
\hline Pohon 3 & $10 \mathrm{~m}$ & 33Tahun & $141 \mathrm{Cm}$ & $15 \mathrm{~cm}$ & $320 \mathrm{Kg}$ \\
\hline Pohon 4 & $9 \mathrm{~m}$ & 19 Tahun & $45,5 \mathrm{~cm}$ & & $160 \mathrm{Kg}$ \\
\hline Pohon 5 & $6 \mathrm{~m}$ & 26 Tahun & $112 \mathrm{Cm}$ & & $180 \mathrm{Kg}$ \\
\hline
\end{tabular}

Source: research results 


\section{c. The total production of gandaria at different heights}

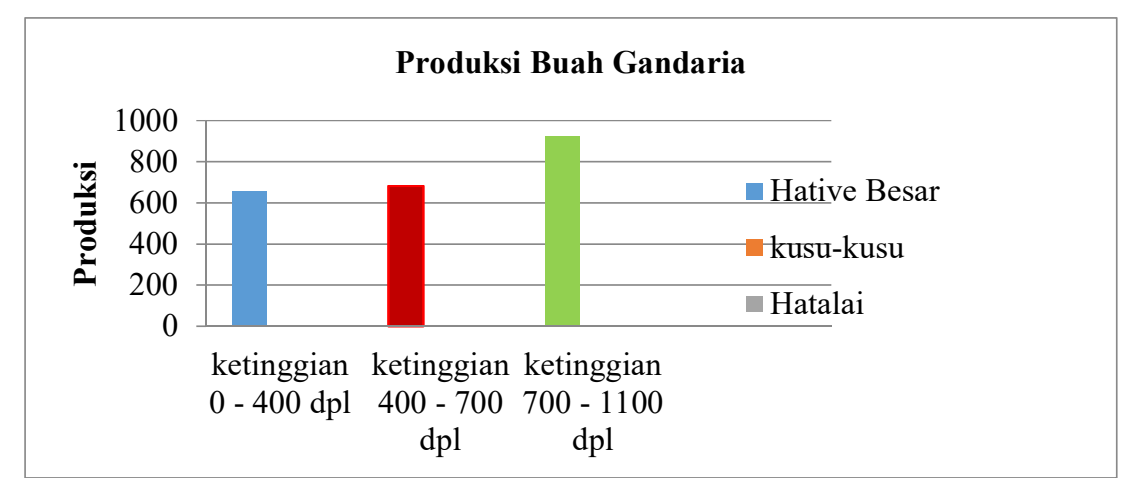

Figure .1 Production of Gandaria Fruit in Different Places

Figure 1 explains the total production at different locations and heights. Measurement of production is important to do because it can provide some information to assess the efficiency and effectiveness of production in gandaria fruit can be used as a basis for taking steps to increase production in the future. Production of Gandaria in Ambon City with a height of $0-400 \mathrm{~m}$ above sea level as a research location in the village of Hative Besar, very little production of Gandaria only reached $654 \mathrm{~kg} /$ tree. Meanwhile, for the production of Gandaria at an altitude of 400-700 m above sea level with research sites in the Kusu-kusu sub-village with a total production of $681 \mathrm{~kg} /$ tree at an altitude of 0-400 $\mathrm{m}$ above sea level and $400-700 \mathrm{~m}$ above sea level has a production value with only a slight difference. The highest value of Gandaria production is at an altitude of $700-1100 \mathrm{~m}$ asl in the Hatalai Hamlet with the amount of $\mathrm{g}$ Gandaria production reaching $925 \mathrm{~kg}$ / tree.

The production of Gandaria in the Great Hative Village with a height of $50 \mathrm{~m}$ above sea level between $0-400 \mathrm{~m}$ above sea level due to differences in the high-low surface of the earth resulting in variations in air temperature (Hasairin, 2010). Variations in air temperature affect the process of fruit formation. If it is lower means the temperature of the air in the area is hotter. Because every 100 meters rises the average temperature drops around 0.5 degrees Celsius. So the lower an area is the hotter the area, and conversely the higher an area the cooler the area. Therefore, the height of the earth's surface influences the production process of Gandaria a fruit (Soumokil, 2012).

The height of the place from the surface of the sea also determines the flowering of plants. Fertilizer plants that are planted in the lowlands flower earlier than those planted in the highlands. Environmental factors will influence the physiological processes in the plants (Kustantini, 2014; Adrian et al, 2014). Kusu-kusu Hamlet between heights of 400-700 m asl total production in the Kusu-kusu Hamlet reaches $681 \mathrm{~kg} /$ tree. Production at an altitude of $400-700 \mathrm{~m}$ above sea level results is greater than at an altitude of 0-400 $\mathrm{m}$ above sea level. This is because the height of the place affects the state and level of fertility and air temperature. Climate is also a factor in influencing growth and productivity. Therefore, the height of a place affects the temperature of an area. The production of Gandaria is also increasing according to the opinion stating that the influence of altitude is mainly related to the process of plant metabolism (Karamoy, 2009). The height of the place from the sea level determines the air temperature and light intensity received by plants at the optimum temperature needed for plants to be best utilized -both by plants. 
From the results of the study in graph 4.1 shows that the height of the place affects the production of Gandaria fruit is indicated by the results of production at an altitude of 700-1100 m above sea level. In Hatalai Hamlet with a altitude of 700-1100 m above sea level of the five trees studied at that altitude can produce $925 \mathrm{~kg} /$ tree. The increase in production of Gandaria fruit is caused at different altitudes, this is due to the location of the planting that affects the air temperature, sunlight, humidity and wind. The altitude is related to the temperature and temperature which is an important factor for plants (Kusmayadi 2013; Rahayu \& Handayani, 2008 \& Setiawan 2009).

Lower temperatures will affect the process of photosynthesis and will also affect plant physiological processes such as the formation of flowers and fruits that are late (Istu, 2010). This causes at the altitude of 700-1100 m above sea level harvest season of the oldest Gandaria compared with an altitude of 0-400 m above sea level. Areas where the air temperature is humid, wet in the tropics, plants are more fertile than areas where the temperature is hot and dry. This statement is evidenced by the results of the production of Gandaria fruit at an altitude of 700-1100 m above sea level whose production value is much compared to the low altitude (Rehata, 2015; Setiawan, 2009).

According to Soetrisno (1998), the climate was greatly changed by altitude. This also affects the process of production of Gandaria fruits where in the higher parts of an area generally more sand is contacted than in the lower parts. At higher elevations the sun's radiation during sunny weather is more intense than lower elevations. Harder winds blow at high elevations than at lower elevations. If the total production data of gandaria is totaled on Ambon Island with 3 fruit production centers, in 2016 the total production is $2,260 \mathrm{~kg}$. The production value is quite a lot when viewed from the many trees used for research with a total of 15 trees.

\section{d. Quality of Gandaria Fruit (Bouea macrophylla Griff) in Each Location and Altitude different}

Table 5 Analysis of Gandaria Fruit Samples

\begin{tabular}{llcccc}
\hline & & \multicolumn{4}{c}{ Quality } \\
\cline { 3 - 6 } No & \multicolumn{1}{c}{ Location } & Water content & Total acid & $\begin{array}{c}\text { Sugar } \\
\text { content }\end{array}$ & pH \\
1. & $\begin{array}{l}\text { Hative besar }(0-400 \mathrm{~m} \\
\text { dpl) }\end{array}$ & $79.89 \%$ & $6,98 \%$ & $12,60 \%$ & 3,9 \\
2. & $\begin{array}{l}\text { Kusu-kusu } \\
\text { dpl) }\end{array}$ & $800-700 \mathrm{~m}$ & $6,96 \%$ & $13,40 \%$ & 3,9 \\
3. & Hatalai $(700-1100 \mathrm{~m} \mathrm{dpl})$ & $80,42 \%$ & $6.51 \%$ & $12,07 \%$ & 4,0 \\
\hline
\end{tabular}

Source: research results

Table 5 explains the quality test of samples of gandaria taken at several locations with different heights on Ambon Island. At the altitude of 0-400 m above sea level in the village of Hative Besar has a water content of slightly $79.89 \%$, while a very large water content is found at a altitude of 700-1100 m above sea level in the Hatalai Hamlet with a water content of $80.42 \%$. For the total acid in gandaria fruit, the total acid is a little at an altitude of 700-1100 m above sea level in the Hatalai Hamlet with a total amount of $6.51 \%$ acid. Meanwhile, for the altitude of $0-400 \mathrm{~m}$ above sea level in the village of Hative Besar with high total acid which reached $6.98 \%$. Sugar content at an altitude of $700-1100 \mathrm{~m}$ above sea level with the location of Hatalai Hamlet with a presentation of $12.07 \%$ is the least sugar content. And a lot of sugar levels are found at an altitude of 0$400 \mathrm{~m}$ above sea level with the location of the Big Hative Village have a high sugar

Received October $10^{\text {th }} 2019$, Revision Februrry $9^{\text {th }} 2020$, Accepted for publication February $18^{\text {th }} 2020$.

Copyright (C) 2020 Published by FKIP - Unpatti, ISSN 2721-3110 
content that is $12.64 \%$. The research location is $0-400 \mathrm{~m}$ above sea level, and $400-700 \mathrm{~m}$ above sea level has the same $\mathrm{pH}$ level of $3.9 \mathrm{pH}$. And the altitude of 700-1100 m above sea level has a $\mathrm{pH}$ value of 4.0 .

\section{1). Water content}

Water content is the percentage of water content of a material that can be expressed based on wet weight (wet basis) or based on dry weight (dry basis). Wet weight water content has a theoretical maximum limit of 100 percent, while water content based on dry weight can be more than 100 percent. (Syarif and Halid, 2008). Fresh fruit offers abundant fiber and water Table 4.4 shows the results of water content in gandaria at various altitudes on Ambon Island with yields at an altitude of $0-400 \mathrm{~m}$ asl in the Hative Besar Village containing a water content of $79.84 \%$, altitude of $400-700 \mathrm{~m}$ asl containing $80.23 \%$ water content and $700-1100 \mathrm{~m}$ height asl containing $80.42 \%$ water content. From the results of the study above shows the higher the height of the gandaria plant where the value of the water content in the fruit also increases.

If the water content of the gandaria fruit is high then the fruit will soften or decrease its hardness, conversely if the water content is small the fruit will show a higher hardness. Water content shows the amount of water contained in gandaria fruit. The difference in water content at different heights is due to, the difference in response in this case lies in the difference in environmental stress obtained by plants. Fitter \& Hay in Fatchurrozak et al. (2013), explained that the response of plant growth characteristics to temperature arises because the high temperature affects the process of forming the quality of gandaria fruit.

In a Mailoa study (2012), stated the water content of gandaria reached $82.92 \%$. This shows that the water content of the gandaria fruit can change according to the height of the place where the gandaria grows. In the research carried out the results obtained an average water content reached $80 \%$ with a ratio of $2 \%$ water content with previous studies. Gandaria fruit has a high water content. In relation to organoleptic testing of fruit suppleness, most of the panelists answered that they were less chewy to chewy, giving effect to the fruit's taste. Fruits with sufficient water content will provide a chewy taste that is suitable and delicious to eat. Mustikasari et al (2001) explain the water content in fruit flesh affects fruit suppleness. Firm elasticity binds water so that the water content becomes balanced. Fruits that are too ripe will contain more water than sugar content.

\section{2). Sugar level}

Table 4.4 shows the results of the research conducted. With the results of the study, Desa Hative Besar (0-400 m asl) with sugar content of $12.60 \%$, Kusu-kusu Hamlet (400-700 m asl) $13.40 \%$ and Hatalai Hamlet $(700-1100 \mathrm{~m}$ asl) $12.07 \%$ of this data can be concluded below that the Kusu-kusu sub-village has a fairly high sugar content compared to other research areas.

The difference in sugar content is caused by one of the factors which affects the fruit sugar content which is greatly influenced by the intensity of the sunlight it catches. In this case plants need bright sunlight and temperatures that are not too low for a process of photosynthesis which is the process of sugar formation. Fruits that have a high sugar content are usually accompanied by acids as well as fruits containing natural sugar.

Sugar content in fruit begins with the maturation process of starches in commodities will turn into sugar and increase sugar levels. This is related to the sweetness level of fresh fruit offers far more than the natural sugar contained in it. The calories provided by fruit come from carbohydrates, which are mostly in the form of fructose, which is a natural sugar in the fruit. With the help of sunlight and the presence of leafy green substances, sugar will be formed from $\mathrm{CO} 2$ from air and water from the soil through the roots in these fruit plants. The longer the process of formation, the more

Received October $10^{\text {th }} 2019$, Revision Februrry $9^{\text {th }} 2020$, Accepted for publication February $18^{\text {th }} 2020$.

Copyright (C) 2020 Published by FKIP - Unpatti, ISSN 2721-3110 
sugar produced directly, this can be seen by tasting the ripe fruit that tastes sweet (Manusiwa, 2008).

Explained by Karamoy, (2009) that the metabolic process of plants is strongly influenced by the height of the place. The process of metabolism includes biochemical processes and the synthesis of secondary metabolite compounds is a factor influencing growth, morphological character, and content of active compounds in a plant (Karamoy, 2009: Fatchurrozak et all, 2013).

The results of tests on Gandaria fruit flesh, the highest sugar content is in the village of Kusu-kusu. Variations of sweetness in Gandaria fruit at different heights are thought to be related to environmental influences, especially climate factors that play a role in plant physiology, because according to Tjasyono, (2004), the existence of changes in environmental temperature greatly affects plant growth and metabolism. Changes in environmental temperature cause changes in plant physiology. Because plants cannot control their body temperature.

\section{e. Simple linear regression test}

The results of a simple linear regression test show there is a relationship between the height of the place to the production and quality of Gandaria fruit in several places.

\begin{tabular}{|l|c|c|c|c|}
\hline \multicolumn{5}{|c|}{ Table 7 ANOVA test } \\
\hline Model & $\mathrm{R}$ & R Square & $\begin{array}{c}\text { Adjusted R } \\
\text { Square }\end{array}$ & $\begin{array}{c}\text { Std. Error of the } \\
\text { Estimate }\end{array}$ \\
\hline 1 & $.883^{\mathrm{a}}$ & .780 & .731 & 155.22516 \\
\hline $\begin{array}{l}\text { a. Predictors: (Constant), Quality, Production } \\
\text { b. Dependent Variable: height of place }\end{array}$ \\
\hline
\end{tabular}

The second table shows the value of $\mathrm{R}$ which is a symbol of the correlation coefficient. In the table above shows the correlation value is 0.883 . This value can be interpreted that the relationship between the two research variables is in the good category. Through this table also obtained the value of R Square or the coefficient of determination (CD) which shows how good the regression model is formed by the interaction of independent variables and dependent variables. CD value obtained is $78.0 \%$ which can be interpreted that the independent variable height of the place has a contribution of $78.0 \%$ to the dependent variable of the production of Gandaria fruit, and the quality of the Gandaria fruit and the other $22 \%$ is influenced by other factors outside the altitude.

\begin{tabular}{|l|l|l|r|r|r|r|}
\hline \multicolumn{7}{|c|}{ Table 6 Test Model Summary } \\
\hline \multirow{2}{*}{ Model } & $\begin{array}{c}\text { Sum of } \\
\text { Squares }\end{array}$ & df & Mean Square & F & Sig. \\
\hline \multirow{3}{*}{1} & Regression & 769813.028 & 2 & 384906.514 & 15.975 & $.001^{\text {a }}$ \\
\cline { 2 - 7 } & Residual & 216853.639 & 9 & 24094.849 & & \\
\cline { 2 - 4 } & Total & 986666.667 & 11 & & & \\
\hline \multicolumn{2}{|l|}{ Predictors: (Constant), Quality, Production } & & & \\
\hline \multicolumn{2}{|l|}{ b. Dependent Variable: height of place } & & & \\
\hline
\end{tabular}

The third table is used to determine the significance or linearity of the regression. The criteria can be determined based on the F test or the Significance value test (Sig). The easiest way with the Sig test, with provisions, if the Sig Value. $<0.05$, then the regression model is linear, and vice versa. Based on the third table, obtained Sig $=0.01$ which means

Received October $10^{\text {th }} 2019$, Revision Februrry $9^{\text {th }} 2020$, Accepted for publication February $18^{\text {th }} 2020$.

Copyright (C) 2020 Published by FKIP - Unpatti, ISSN 2721-3110 
$<$ significant criteria (0.05), thus the regression equation model based on research data is very significant, the height of the place greatly affects the production and quality of Gandaria on Ambon Island. This is due to the height of the place associated with temperature and humidity, the higher a place, the lower the temperature and higher humidity. altitude correlates with temperature, and temperature differences affect changes in other climatic factors such as rainfall, humidity, intensity of sunlight, and wind speed (Sangadji, 2001); Saleh, \& Hatmoko, 2010)

\begin{tabular}{|c|c|c|c|c|c|c|}
\hline \multicolumn{7}{|c|}{ Tabel 9. Coefficients Test } \\
\hline & & \multicolumn{2}{|c|}{ Unstandardized Coefficients } & \multirow{2}{*}{$\begin{array}{c}\begin{array}{c}\text { Standardized } \\
\text { Coefficients }\end{array} \\
\text { Beta }\end{array}$} & \multirow[b]{2}{*}{$\mathrm{t}$} & \multirow[b]{2}{*}{ Sig. } \\
\hline \multicolumn{2}{|c|}{ Model } & $\mathrm{B}$ & Std. Error & & & \\
\hline \multirow[t]{3}{*}{1} & (Constant) & -7582.047 & .000 & & $-1.811 \mathrm{E} 7$ & .000 \\
\hline & production & .839 & .000 & 1.203 & $7.870 \mathrm{E} 7$ & .000 \\
\hline & Quality & 27.349 & .000 & .263 & $1.719 \mathrm{E} 7$ & .000 \\
\hline \multicolumn{4}{|c|}{ a. Dependent Variable: height of place } & & & \\
\hline
\end{tabular}

With a constant value of 7582,047 , the regression equation has the following meanings: a constant of 7582,047 means that with a different altitude, the total production is 7582 per kilo if the variable height increases, it will cause an increase in production of $839 \mathrm{~kg}$ at a higher altitude high.

With a constant value of 7582,047 , the regression equation has the following meanings: a constant of 7582,047 and a value of sig $000<0.05$ then with the existence of different heights, the quality of the Gandaria is significantly influenced by different heights. so that it can be concluded that the hypothesis Ho is rejected and Ha is accepted.

\section{Conclusion}

The conclusions that can be drawn from the results of this study are:

1. The relationship between the amount of production of Gandaria fruit with the height of the place that is the higher the place of the sea surface, the more the production of Gandaria also increases. The average production of Gandaria at an altitude of 700$1100 \mathrm{~m}$ above sea level is nine hundred twenty-five $\mathrm{kg}$. Whereas for medium altitude the production of Gandaria fruit reaches six hundreds of Gandaria

2. The relationship of altitude above sea level with the quality of the Gandaria fruit also affects the quality of the Gandaria itself with an average total sugar of $12.69 \%$, a water content of $80.18 \%$, an acidity level of $6.81 \%$ and a $\mathrm{pH}$ of 3 .

\section{References}

Andrian, Supriadi, Purba Marpaung, 2014. Pengaruh Ketinggian Tempat dan Kemiringan Lereng Terhadap Produkti Karet (Hevae brasiliensis Muell. Arg) Di Kebun Hapesong PTPN III Tapanuli Selatan. Jurnal Online Agroekoteknologi . Vol.2, No.3 : $981-989$.

Bratawinata, A. 2001. Ekologi Hutan Hujan Tropis Dan Metode Analisis Hutan. Departemen Pendidikan Nasional Direktorat Jenderal Pendidikan Tinggi Badan Kerja sama Perguruan Timggi Negeri Indonesia Timur. Samarinda. BKS - PTN INTIM.

Received October $10^{\text {th }} 2019$, Revision Februrry $9^{\text {th }} 2020$, Accepted for publication February $18^{\text {th }} 2020$.

Copyright (C) 2020 Published by FKIP - Unpatti, ISSN 2721-3110 
Broto, W., 2003. Mangga: Budidaya, Pasca Panen dan Tata Niaganya. Agromedia Pustaka. Jakarta.

Desrosier, N, W. 2012 Teknologi Pengawetan Pangan, Terjemahan Oleh M. Mulyoharjo, Ui Press.

Gaman, P., P-K. B. Sherrington. 2011 Pengantar Ilmu Pangan, Nutrisi Dan Mikrobiologi. Gajahmada Press.

Hardjadi,S.S, Widodo dan Suketi, 2011. Aspek-Aspek Penting Budidaya Tanaman Buah-buahan.https://agroinfotek.files.wordpress.com/2011/04/aspekpentingtanaman-buah.pdf

Hasairin, A. 2010. Botani Sistematika Domestic Collaborative Research Grant Program URGE Project. Departemen Pendidikan Nasional.

Heyne, K. 1987. Tumbuhan Berguna Indonesia. Alih Bahasa Badan Litbang Kehutanan. Jakarta: Departemen Kehutanan.

Istu, Walila. 2010. Pengaruh ketinggian tempat terhadap pertumbuhan tanaman kacang panjang (Vigna Sinensis Endl) di dusun Waitomu Desa Hila kecamatan Leihitu Kabupaten Maluku Tenggah. Skripsi. Universitas Pattimura Ambon.

Fatchurrozak, Suranto, dan Sugiyarto, 2013. Pengaruh Ketinggian Tempat Terhadap Kandungan Vitamin C dan Zat Antioksidan Pada Buah Carica pubescens Di Dartaran Tinggi Dieng. Jurnal EL-VIVO Vol.1, No.1, hal 24 - 31, September 2013

Karamoy, L. 2009. Hubungan Antara Iklim dengan pertumbuhan Kedelai (Glicine max L. Merrill). Soil Environment. 7(1): 65-68.

Kurniawan, M. B., P. Bayu. 2010.Mengenal Hewan Dan Flora Asli Indonesia. Cikal Aksara. Jakarta.

Kusmayadi, W.,(2013),Pengaruh Pemberian Beberapa Jenis Bokashi Dan Dosis Organik Cair (Super aci) Terhadap Pertumbuhan Bibit Jambu Mete (Annacardium occidentale (L.) Di Persemaian.

Kustantini, D. 2014. Pentingnya Konservasi Tanah Pada Pengelolaan Kebun Sumber Benih Kopi (PBT Ahli Pertama) Balai Besar Perbenihan dan Proteksi Tanaman Perkebunan (BBPPTP) Surabaya

Mailoa, Meitycorfrida, 2012. Pengaruh Natrium Benzoat Dan Lama Penyimpanan Terhadap Mutu Selai Gandaria. Universitas Pattimura Ambon Vol 01, No : 01 agustus 2012 ISSN 2337-5329

Manusiwa, Yurisyensi. 2008. Pengaruh berbagai tingkat kematangan buah gandaria terhadap kandungan gula (skripisi) fakultas keguruan dan ilmu pendidikan Universitas Pattimura. Ambon

Monteith, J.L. 1977. Climate. P. 1-27. In P de T. Alium and T.T. Kozlowski, eds. Ecophysiology of Tropical Crops. Acad. Press Nerw York.

Monk, K.A, De Fretes, Y dan Lelley, G.R. 2000. Ekologi Nusa Tenggara dan Maluku. Alih Bahasa Kartikasari, S.N. Jakarta: Prenhallindo.

Mulyawanti, ira, Dewandari K. T, Yulianingsih. 2008 pengaruh waktu pembekuan dan penyimpanan terhadap Karakteristik irisan buah mangga arumanis beku. Hlm 51 - 58. Balai Besar Penelitian dan Pengembangan Pascapanen Pertanian Bogor

Nasution, I.S., 2003. Pengaruh Penggunaan Lapisan Edible (Edible Coating), Kalsium Klorida, dan Kemasan Plastik Terhadap Mutu Nanas (Ananas comosus Merr.) Terolah Minimal. Jurnal Teknologi dan Industri Pertanian Indonesia, 4(2): 21-26.

Pancoro, H. A., Kusumawati, D. \& Ediathong, W. (2011). "Molecular Diservication and Phylogeny of Mangifera (Anacardiaceae) in Indonesia and Thailand". Proceeding of The International Conference on Advanced Science, Engineering and Information Technology.

Pracaya. 2002. Bertanam Mangga. Jakarta. PT Penebar Swadaya, Anggota Ikapi.

Primack, R. B. 1994. Biologi Konservasi. Jakarta. Yayasan Obor Indonesia

Received October $10^{\text {th }} 2019$, Revision Februrry $9^{\text {th }} 2020$, Accepted for publication February $18^{\text {th }} 2020$.

Copyright (C) 2020 Published by FKIP - Unpatti, ISSN 2721-3110 
Rahayu, S.E. \& Handayani, S. 2008. Keanekaragaman Morfologi dan Anatomi Pandanus (Pandanaceae) di Jawa Barat. VIS VITALIS, Vol 01.No 2.

Rehatta, H. 2005. Potensi Dan Pengembangan Tanaman Gandaria (Bouea Macrophylla Griffth) Di Desa Soya Kecamatan Sirimau Kota Ambon.Lemlit Universitas Pattimura Ambon

Saleh, M. Mawardi M., Eddy W. Dan D. Hatmoko, 2010. Determinasi Dan Morfologi Buah Eksotis Potensial Di Lahan Rawa. Balai Penelitian Pertanian Lahan Rawa Banjarbaru

Salisbury, K.B, dan Ross, C.W. 1995. Fisiologi Tumbuhan Jilid 3. Alih Bahasa Lukman, D.R. Bandung: ITB.

Santoso Bb, A Budianto, Aryana Igpm. 2012. Seed Viability Of Jatropha Curcas Indifferent Fruit Maturity Stages After Storage. Bioscience. 4(3):113-117

Setiwan Eko .2009 .Kajian Ketinggian Tempat Dan Produktivitas Cabe Jamu. Vol 2 No 1.Madura : penerbit Universitas Trunojo Madura

Soumokil Benjamin. Th., 2012 Strategi Pengelolaan Ekowisata Pada Kawasan Hutan Lindung Gunung Sirimau (Kasus : Desa Soya Kecamatan Sirimau Kota Ambon

Soetrisno, T. 1958. Fisiologi dan Teknologi Pascapanen. Penerbit Akademika Yogyakarta.

SyamsudinI.,2007. Buah Langka Indonesia, Pada Http://Www.Proseanet.Org/Florakita, Diakses Tanggal 24 Januari 2019 Schard.) Terhadap Konsentrasi Paclobutrazol Dan Dosis Pupuk Npk

Sangadji, S. 2001. Pengaruh Iklim Tropis di Dua Ketinggian Tempat yang Berbeda Terhadap Potensi Hasil Tanaman Soba (Fagopyrum esculentum Moench.). Tesis. IPB, Bogor.

Tjasyono, B. 2004. Klimatologi. Edisi Ke Dua. Bandung. Institut Tekhnologi Bandung

Taihuttu, H, N. 2013. Identifikasi Karakteristik Lahan Tanaman Gandaria (Bouea Macrophylla Griff) Di Desa Hunuth Kecamatan Baguala Kota Ambon. Jurusan Budidaya Pertanian Fakultas Pertanian Universitas Pattimura Ambon.

Taihuttu, H. N. 2011. Identification Of Characterization Land Of Gandaria (Bouea Macrophylla Griff) In Hative Besar Ambon Bay Districh Ambon. Poster. Seminar International Humanosphere. Ambon.

Tangkuman, C. 2006. Identifikasi Potensi Tanaman Gandaria (Bouea Macrophylla Griff) Di Dusun Kusu .- Kusu Sereh Desa Urimesing Kecamatan Nusaniwe Kota Ambon. [Skripsi] Universitas Pattimura. Ambon

Whitten, A.J.,SJ Damanik, J. Anwar and Hisyam. 1984. The Ecology of Sumatra. Gadjahmada University Press, Yogyakarta 